BMJ Open

Diabetes

Research

\& Care

\title{
Hemoglobin A1c in combination with fasting plasma glucose trumps fasting plasma glucose alone as predictive indicators for diabetes mellitus: an ambidirectional cohort study of Thai people with impaired fasting glucose
}

Sangsulee Thamakaison, ${ }^{1}$ Thunyarat Anothaisintawee (D) , ${ }^{1,2}$ Kanokporn Sukhato, ${ }^{1}$ Nattawut Unwanatham, ${ }^{2}$ Sasivimol Rattanasiri, ${ }^{2}$ Sirimon Reutrakul, ${ }^{3}$ Ammarin Thakkinstian ${ }^{2}$

To cite: Thamakaison S, Anothaisintawee T, Sukhato K, et al. Hemoglobin A1c in combination with fasting plasma glucose trumps fasting plasma glucose alone as predictive indicators for diabetes mellitus: an ambidirectional cohort study of Thai people with impaired fasting glucose. BMJ Open Diab Res Care 2021;9:e002427. doi:10.1136/ bmjdrc-2021-002427

- Additional supplemental material is published online only. To view, please visit the journal online (http://dx.doi. org/10.1136/bmjdrc-2021002427).

Received 8 June 2021 Accepted 5 November 2021

Check for updates

(c) Author(s) (or their employer(s)) 2021. Re-use permitted under CC BY-NC. No commercial re-use. See rights and permissions. Published by BMJ.

For numbered affiliations see end of article.

Correspondence to Dr Thunyarat Anothaisintawee; thunyarat.ano@mahidol.ac.th

\section{ABSTRACT}

Introduction This ambidirectional cohort study aimed to assess the performance of combining hemoglobin A1c ( $\mathrm{HbA1c}$ ) to fasting plasma glucose (FPG) for estimation of progression rate to diabetes mellitus (DM) and to explore the risk factors of DM in patients with impaired fasting glucose (IFG).

Research design and methods Patients with IFG were eligible for this study. IFG was defined as FPG of 100$125 \mathrm{mg} / \mathrm{dL}$. Progression rates to DM were estimated using Kaplan-Meier analysis. Risk factors of DM were explored by Cox regression analysis.

Results 3011 patients were enrolled with median follow-up time of 8 years (range: 6 months-29 years). Progression rates to DM in patients with FPG $100-109 \mathrm{mg} /$ $\mathrm{dL}$ and $110-125 \mathrm{mg} / \mathrm{dL}$ were 2.64 and 4.79 per 100 person-years. After adjusting covariables, compared with patients with FPG 100-109 mg/dL plus normal HbA1c $(<5.7 \%)$, hazard ratios $(95 \% \mathrm{Cl})$ of patients with $\mathrm{FPG}$ 110-125 plus normal HbA1c, FBG 100-109 plus abnormal HbA1c (5.7\%-6.49\%), and FPG 110-125 plus abnormal HbA1c were 5.89 (2.37 to 14.63), 16.30 (8.59 to 30.92), and 33.84 (16.41 to 69.78), respectively. Body mass index $\geq 27.5 \mathrm{~kg} / \mathrm{m}^{2}$, serum triglyceride level $\geq 150 \mathrm{mg} / \mathrm{dL}$, family history of DM, and low level of high-density lipoproteincholesterol were independently associated with risk of DM in patients with IFG.

Conclusions Patients with both IFG and abnormal HbA1c had higher risk of DM than patients with IFG alone. Therefore, performing $\mathrm{HbA1c}$ in combination with FPG helps to identify subgroups of people with IFG at highest risk of DM. These patients should have the highest priority in diabetes prevention programs, especially in countries with low and limited resources.

\section{INTRODUCTION}

Pre-diabetes is recognized as an intermediate stage between normoglycemia and overt diabetes mellitus (DM). ${ }^{1}$ The population with

\section{Significance of this study}

What is already known about this subject?

- Patients with pre-diabetes have significantly higher risk of diabetes mellitus (DM) than people with normoglycemia. However, different criteria are applied to define pre-diabetes status and may confer the different risks of developing DM.

What are the new findings?

- Progress rate to DM was highest (5.46 per 100 person-years) in patients having fasting plasma glucose of $110-125 \mathrm{mg} / \mathrm{dL}$ with abnormal hemoglobin A1c (HbA1c) (5.7\%-6.49\%). This was significantly higher than progression rate in patients having fasting plasma glucose $100-109 \mathrm{mg} / \mathrm{dL}$ with normal HbA1c level (0.24 per 100 person-years).

- Body mass index $\geq 27.5 \mathrm{~kg} / \mathrm{m}^{2}$, serum triglyceride level $\geq 150 \mathrm{mg} / \mathrm{dL}$, and having family history of DM significantly increased risk of diabetes in patients with impaired fating glucose.

- Contrastingly, high level of high-density lipoproteincholesterol significantly decreased risk of DM in patients with impaired fasting glucose.

How might these results change the focus of research or clinical practice?

- Using HbA1C in combination with fasting plasma glucose for screening DM is beneficial for classifying people who are at high risk of DM. Patients having fasting plasma glucose of $110-125 \mathrm{mg} / \mathrm{dL}$ with abnormal $\mathrm{HbA1C}$ should have the highest priority in diabetes prevention programs, especially in countries with low and limited resources.

pre-diabetes is at a high risk not only of overt type $2 \mathrm{DM}^{12}$ but also cardiovascular diseases (CVDs) and all-cause mortality, ${ }^{34}$ as microvascular and macrovascular changes are present 
since the onset of glycemic dysregulation. ${ }^{5}$ Therefore, pre-diabetes should be treated to decrease the probability of progression to DM and prevent the potential effects of pre-diabetes itself. ${ }^{6}$

Diagnostic criteria used for defining pre-diabetes have been changed over time and also varied depending on the institutions of origin. For instance, the American Diabetes Association (ADA) ${ }^{7}$ defines pre-diabetes as (1) impaired glucose tolerance (IGT), that is, 2-hour glucose level of $140-199 \mathrm{mg} / \mathrm{dL}$ after a 75 -gram oral glucose load; (2) impaired fasting glucose (IFG), that is, fasting plasma glucose (FPG) level of 100-125 mg/dL; or (3) abnormal hemoglobin Alc (HbAlc) of $5.7 \%-6.49 \%^{7}$; whereas the WHO defines IFG as FPG level of $110-125 \mathrm{mg} / \mathrm{dL},{ }^{8}$ and the International Expert Committee (IEC) defines abnormal HbA1c as HbA1c of 6.0\%-6.49\%.

Despite being the same 'pre-diabetes' category, there is evidence that differences in glycemic indices confer different risks of DM progression. ${ }^{9}{ }^{10}$ For instance, the results from a meta-analysis found that the risk of DM progression in people with $\mathrm{HbA1c}$ of $5.7 \%-6.49 \%$ was higher than risk in people with FPG $100-125 \mathrm{mg} / \mathrm{dL},{ }^{11}$ and people with both IFG and HbAlc might have a higher risk than people with either IFG or abnormal HbA1c. This difference may result from different underlying pathogeneses between IFG and abnormal HbAlc. ${ }^{12}{ }^{13}$ In addition, different thresholds of FPG level used for defining pre-diabetes would affect the magnitude of prevalence and burden of pre-diabetes globally. For instance, lowering the threshold of FPG level will increase the prevalence of pre-diabetes, which may pose as an issue to low/middle-income countries with limited healthcare and economic resources. Therefore, this ambidirectional cohort study primarily aiming to assess whether performing HbAlc in combination with FPG could improve the ability to predict diabetes risk more than performing FPG alone and to estimate the progression rate to DM according to different criteria of IFG. Additional factors (eg, body mass index (BMI), family history of DM, and history of hypertension), known to be associated with DM risk, ${ }^{10} 14$ will also be considered. The results from this study will be useful in identifying people with IFG who are at a high risk of progression to DM, enabling group-specific diabetes prevention strategies and allowing efficient utilization of resources in limited settings.

\section{METHODS}

This study was an ambidirectional cohort of patients with IFG that combined retrospective with prospective data collection. Patients with IFG who visited the outpatient clinic of the Department of Family Medicine, Ramathibodi Hospital, Bangkok, Thailand during October 2014 through October 2017 were enrolled for this study, and they were followed until January 2019 for this analysis. IFG was defined according to the ADA criteria (ie, FPG ranging from 100 to $125 \mathrm{mg} / \mathrm{dL}$ ). Patients were excluded, if they took anti-diabetic medications or were not willing to participate in the study.

\section{Data collection}

Three methods were applied for data collection as follows: (1) demographic data (eg, age, sex, marital status, education), family history of DM, health risk behavior (eg, smoking and alcohol drinking), and risk of obstructive sleep apnea (OSA) were obtained from interviewing by well-trained research assistants. Risk of OSA was assessed by adapting the questions from category I of Berlin questionnaire ${ }^{15}$ asking about presence and severity of snoring, and frequency of cessation of breathing during sleep. Participants were classified as being high risk of OSA, if the total score of this category was equal or greater than 2. Height and waist circumference were obtained at the time of enrollment by trained research assistants. Height was measured without shoes to the nearest $0.1 \mathrm{~cm}$. Waist circumference $(\mathrm{cm})$, to the nearest $0.1 \mathrm{~cm}$, was measured at the middle point between the lowest rib and iliac crest in the standing position using a plastic tape. (2) Date of IFG diagnosis and history of underlying diseases (ie, chronic kidney disease (CKD), CVD, hypertension, dyslipidemia, gestational DM, and cancer) were collected through medical record reviews by trained physicians. (3) Body weight, systolic blood pressure (SBP), diastolic blood pressure (DBP), and laboratory data including FPG, HbAlc, serum uric acid, triglyceride, high-density lipoprotein-cholesterol (HDLC), low-density lipoprotein-cholesterol (LDL-C) were retrieved from the Medical Statistics Unit, Ramathibodi Hospital since the date of IFG diagnosis to the date of last follow-up or the end date of the study (31 January 2019). These laboratory assays were performed in the clinical laboratory of Ramathibodi Hospital. FPG was measured using hexokinase glucose- 6 phosphate dehydrogenase. HbA1c levels were measured using turbid metric inhibition immunoassay that has been certified by the National Glycohemoglobin Standardization Program. Serum triglyceride and serum uric acid levels were measured by lipase/glycerol kinase glycerol-3-phosphate oxidase and uricase methods, respectively. HDL-C and LDL-C levels were measured by accelerator selective detergent method.

BMI was calculated by dividing weight in kilogram with height in square meter and then classified into normal weight $\left(\mathrm{BMI}<23 \mathrm{~kg} / \mathrm{m}^{2}\right.$ ), overweight (BMI $23-27.49 \mathrm{~kg}$ / $\mathrm{m}^{2}$ ), and obesity (BMI $\geq 27.5 \mathrm{~kg} / \mathrm{m}^{2}$ ) in accordance with WHO recommendations for Asian population. ${ }^{16}$ Age of participants was calculated based on the date of IFG diagnosis and categorized into three groups as $(1)<65$ years, (2) 65-74 years, and (3) $\geq 75$ years. SBP and DBP levels incorporated with history of hypertension were categorized into three groups as (1) normal blood pressure (ie, $\mathrm{SBP}<140$ and $\mathrm{DBP}<90 \mathrm{~mm} \mathrm{Hg}$ ) without history of hypertension, (2) well-controlled blood pressure (ie, SBP $<140$ and DBP $<90 \mathrm{~mm} \mathrm{Hg}$ ) with history of hypertension and/or antihypertensive drugs, and (3) high blood 
pressure (ie, $\mathrm{SBP} \geq 140$ and/or $\mathrm{DBP} \geq 90 \mathrm{~mm} \mathrm{Hg}$ ) with or without history of hypertension. Serum uric acid was classified into normal uric acid level and hyperuricemia (ie, serum uric acid $\geq 6.2 \mathrm{mg} / \mathrm{dL}$ in female and $\geq 7.2 \mathrm{mg} / \mathrm{dL}$ in male). Triglyceride, LDL-C, and HDL-C levels were categorized into normal and high triglyceride $(\geq 150 \mathrm{mg} / \mathrm{dL})$, high LDL-C $(\geq 130 \mathrm{mg} / \mathrm{dL})$, and low HDL-C $(\leq 40 \mathrm{mg} / \mathrm{dL}$ in male and $\leq 50 \mathrm{mg} / \mathrm{dL}$ in female) levels.

Baseline FPG measured at the date of IFG diagnosis was used for prediction of the DM progression. FPG was classified into two groups as (1) FPG 100-109 mg/dL and (2) FPG 110-125 mg/dL. Abnormal HbAlc was defined as HbA1c of $5.7 \%-6.49 \%$. When considering both FPG and HbA1c together, participants were classified into four groups as (1) FPG $100-109 \mathrm{mg} / \mathrm{dL}$ with normal HbA1c $\left(\right.$ FPG $_{100-109}$ and HbA1c $\left.\mathrm{c}_{<5.7}\right)$, (2) FPG $110-125 \mathrm{mg} /$ $\mathrm{dL}$ with normal HbA1c $\left(\mathrm{FPG}_{110-125}\right.$ and $\left.\mathrm{HbAlc}_{<5.7}\right)$, (3) FPG $100-109 \mathrm{mg} / \mathrm{dL}$ with abnormal HbAlc $\left(\mathrm{FPG}_{100-109}\right.$ and $\mathrm{HbAlc}_{5.7-6.49}$ ), and (4) FPG $110-125 \mathrm{mg} / \mathrm{dL}$ with abnormal HbA1c $\left(\mathrm{FPG}_{110-125}\right.$ and $\left.\mathrm{HbAlc}_{5.7-6.49}\right)$. HbAlc measured within 2 years after diagnosis of IFG was used for prediction of DM in patients who had not measured $\mathrm{HbAlc}$ at the time of IFG diagnosis.

Outcome of interest was time since IFG diagnosis to DM progression, which was defined by FPG of $126 \mathrm{mg} /$ $\mathrm{dL}$ or higher, and/or HbA1c of $6.5 \%$ or higher on one occasion during follow-up time. ${ }^{17}$ This definition was used only for the purposes of the epidemiological study, which had also been applied by previous studies. ${ }^{18-20}$ All FPG and HbAlc values measured during the time of follow-up were used for outcome verification.

\section{Multiple imputations}

Baseline or fixed variables were missing which ranged from $0.03 \%$ (family history of DM) to $68.95 \%$ (HbAlc value at time of IFG diagnosis) (see online supplemental table 1), while time-varying variables were missing which ranged from $0.01 \%$ to $45.9 \%$ (see online supplemental table 2). The multiple imputation with chain equation was performed with 70 and 30 for fixed and time-varying variables, respectively. Type of predictors and model used were described in online supplemental table 3 , including logit and linear regression models for categorical/ ordinal and continuous variables. A maximum fraction of missing information (FMI) was used to assess if a number of imputations were sufficient, that is, the maximum FMI of 0.30 would require at least 30 imputations.

\section{Statistical analysis}

Demographic data were presented as mean and standard deviation (SD) for continuous data and as frequency and percentage for categorical data. Time to DM progression was calculated as the subtraction of progression date with date of IFG diagnosis (starting date). Patients who were free from DM progression were censored on the end date of study (31 January 2019) or the date of last visit if they were lost to follow-up. Progression rates to DM according to different cut-off points of FPG and HbAlc levels were estimated. In addition, probability of DM progression at different times was estimated using Kaplan-Meier analysis.

Potential factors associated with DM progression were collected including age, sex, educational level, family history of DM, smoking, alcohol drinking, OSA risk, underlying diseases, BMI, SBP, DBP, and laboratory values (ie, serum uric acid, triglyceride, LDL-C, and HDL-C). Some of them (ie, BMI, SBP, DBP, triglyceride, serum uric acid, LDL-C, and HDL-C levels) were changed over time during the follow-up, thus they were considered as time-varying covariates. Data were prepared as long format, in which each participant had multiple records according to number of visits at the outpatient clinic and/or occurrence of DM progression. A survival analysis was performed based on multiple-record data with a single event to estimate DM progression rate. Prognostic factors of DM progression were assessed using Cox proportional hazard model with time-varying covariates. Variables that had a $p$ value less than 0.1 were then considered in a multivariate Cox proportional hazard model. A likelihood ratio test was applied to select only significant prognostic factors in the final model that contained FBG or HbA1c groups. A proportional hazard assumption between FBG/HbAlc groups was checked using a global $\chi^{2}$ test and $\log -\log$ (survival) plot. If the assumption was violated, that is, effects of $\mathrm{FBG} / \mathrm{HbAlc}$ were not proportional over time, an interaction between $\mathrm{FBG} / \mathrm{HbA1c}$ and time variable was added in a Cox regression model. All statistical analyses were performed using STATA program V.16. A two-sided $p$ value less than 0.05 was considered as statistically significant.

\section{Role of the funding source}

This study was supported by the Faculty of Medicine, Ramathibodi Hospital, Mahidol University. The funding of this study was not involved in study design, data collection, data analysis, data interpretation and report writing.

\section{RESULTS}

A total of 3019 patients with IFG were enrolled during the study period; 8 patients were later excluded due a lack of follow-up visits, leaving 3011 patients included in the study. The baseline characteristics of patients in overall and according to combined FPG and HbAlc categories are presented in table 1 . The mean age was $64.1( \pm 9.3)$ years and the majority of the participants were female $(65.9 \%)$. The majority of participants were married $(69.7 \%)$ and received a healthcare reimbursement under civil servant system (59.6\%). About one-fourth and nearly half of patients were ex-smokers or current smokers $(24.4 \%)$ and ex-alcohol drinkers or current alcohol drinkers $(46 \%)$. Nearly half of the participants reported a familial history of DM (40\%). Most participants had comorbidities of hypertension $(68.1 \%)$ and dyslipidemia $(88.7 \%)$. The mean BMI was $26.3( \pm 4.0)$ $\mathrm{kg} / \mathrm{m}^{2}$. The mean levels of SBP and DBP were 137.1 $( \pm 14.1)$ and $77.0( \pm 6.3) \mathrm{mm} \mathrm{Hg}$, respectively. The male 
Table 1 Characteristics of study's participants

\begin{tabular}{|c|c|c|c|c|c|}
\hline Characteristics & $\begin{array}{l}\text { Total } \\
\mathrm{N}=3011\end{array}$ & $\begin{array}{l}\text { FPG } 100-109 \mathrm{mg} / \mathrm{dL} \\
\text { and HbA1c }<5.7 \% \\
\text { ( } \mathrm{N}=223 \text { ) }\end{array}$ & $\begin{array}{l}\text { FPG } 100-109 \mathrm{mg} / \mathrm{dL} \\
\text { and HbA1c } 5.7 \%-6.49 \% \\
\text { (N=456) }\end{array}$ & $\begin{array}{l}\text { FPG } 110-125 \mathrm{mg} / \mathrm{dL} \\
\text { and } \mathrm{HbA1c}<5.7 \% \\
(\mathrm{~N}=68)\end{array}$ & $\begin{array}{l}\text { FPG } 110-125 \mathrm{mg} / \mathrm{dL} \\
\text { and HbA1c } 5.7 \%-6.49 \% \\
\text { ( } \mathrm{N}=209)\end{array}$ \\
\hline $\begin{array}{l}\text { Age at enrollment (year): mean } \\
\text { (SD) }\end{array}$ & $64.1(9.25)$ & $59.4(9.51)$ & $62.0(8.45)$ & $60.5(8.62)$ & $61.4(9.17)$ \\
\hline Female: frequency (\%) & 1985 (65.92) & $140(62.78)$ & $310(67.98)$ & $36(52.94)$ & $137(65.55)$ \\
\hline $\begin{array}{l}\text { Duration of pre-diabetes at } \\
\text { date of enrollment (year); } \\
\text { median (range) }\end{array}$ & $4.91(0.25-23.47)$ & $2.55(0.50-3.91)$ & $2.78(0.52-4.18)$ & $2.58(0.65-3.67)$ & $2.47(0.38-3.98)$ \\
\hline \multicolumn{6}{|l|}{ Educational level: frequency (\%) } \\
\hline Lower than primary school & $82(2.73)$ & $4(1.79)$ & $11(2.42)$ & $0(0)$ & 7 (3.35) \\
\hline Primary school & $971(32.35)$ & $69(30.94)$ & $129(28.35)$ & 24 (35.29) & $66(31.58)$ \\
\hline Secondary school & $864(28.78)$ & 70 (31.39) & $130(28.57)$ & $18(26.47)$ & $57(27.27)$ \\
\hline College or higher & $1085(36.14)$ & $80(35.87)$ & $185(40.66)$ & $26(38.24)$ & $79(37.80)$ \\
\hline \multicolumn{6}{|l|}{ Marital status: frequency (\%) } \\
\hline Single & $368(12.24)$ & $29(13.0)$ & $59(12.94)$ & $8(11.76)$ & $21(10.10)$ \\
\hline Married & 2094 (69.66) & $160(71.75)$ & $310(67.98)$ & $53(77.94)$ & $153(73.56)$ \\
\hline Divorce & $228(7.58)$ & $15(6.73)$ & $40(8.77)$ & $1(1.47)$ & $20(9.62)$ \\
\hline Widow & $316(10.51)$ & $19(8.52)$ & $47(10.31)$ & $6(8.82)$ & $14(6.73)$ \\
\hline \multicolumn{6}{|l|}{ Reimbursement: frequency (\%) } \\
\hline $\begin{array}{l}\text { Universal healthcare } \\
\text { coverage }\end{array}$ & $55(1.84)$ & $8(3.64)$ & $7(1.55)$ & $0(0)$ & $9(4.33)$ \\
\hline Social security scheme & $284(9.52)$ & $27(12.27)$ & $41(9.07)$ & $5(7.69)$ & $20(9.62)$ \\
\hline Civil servant & $1777(59.55)$ & $126(57.27)$ & $274(60.62)$ & $40(61.54)$ & $127(61.06)$ \\
\hline Others & 868 (29.09) & $59(26.82)$ & $130(28.76)$ & $20(30.77)$ & $52(25.0)$ \\
\hline \multicolumn{6}{|l|}{ Smoking status: frequency (\%) } \\
\hline Never & $2278(75.66)$ & $166(74.44)$ & $351(76.97)$ & $46(67.65)$ & $9(4.31)$ \\
\hline Past smoker & $613(20.36)$ & $46(20.63)$ & $87(19.08)$ & $16(23.53)$ & 47 (22.49) \\
\hline Current smoker & $120(3.99)$ & $11(4.93)$ & $18(3.95)$ & $6(8.82)$ & $153(73.21)$ \\
\hline \multicolumn{6}{|l|}{ Alcohol drinking: frequency (\%) } \\
\hline Never & 1625 (54.02) & $110(49.55)$ & 255 (55.92) & $31(45.59)$ & $99(47.37)$ \\
\hline Past drinking & $796(26.46)$ & $56(25.23)$ & $111(24.34)$ & $22(32.35)$ & $64(30.62)$ \\
\hline Current drinking & $587(19.51)$ & $56(25.23)$ & $90(19.74)$ & $15(22.06)$ & $46(20.01)$ \\
\hline $\begin{array}{l}\text { Having family history of } \\
\text { diabetes mellitus }\end{array}$ & $1205(40.03)$ & $83(37.22)$ & $202(44.30)$ & $20(29.41)$ & $96(46.15)$ \\
\hline \multicolumn{6}{|c|}{ Underlying diseases: frequency (\%) } \\
\hline Hypertension & $2044(68.09)$ & $123(55.16)$ & 297 (65.71) & $43(63.24)$ & $132(63.46)$ \\
\hline Dyslipidemia & $2665(88.74)$ & $182(81.61)$ & $398(87.86)$ & $55(80.88)$ & $182(87.50)$ \\
\hline Chronic kidney disease & $123(4.10)$ & $6(2.69)$ & $21(4.65)$ & $5(7.35)$ & $9(4.33)$ \\
\hline Coronary artery disease & $16(0.53)$ & $1(0.45)$ & $2(0.44)$ & $0(0)$ & $2(0.96)$ \\
\hline Cerebrovascular disease & $38(1.27)$ & $4(1.79)$ & $6(1.33)$ & $0(0)$ & $3(1.44)$ \\
\hline Fatty liver & $118(3.93)$ & $12(5.38)$ & $22(4.87)$ & $2(2.94)$ & $11(5.29)$ \\
\hline $\begin{array}{l}\text { Gestational diabetes } \\
\text { mellitus }\end{array}$ & $16(0.81)$ & $0(0)$ & $4(1.29)$ & $0(0)$ & $5(3.65)$ \\
\hline Cancer & $54(2.73)$ & $6(4.29)$ & $7(2.29)$ & $1(2.78)$ & $5(3.68)$ \\
\hline $\begin{array}{l}\text { Berlin category I } \geq 2 \text { : frequency } \\
\text { (\%) }\end{array}$ & 1203 (39.95) & $43(30.71)$ & $111(35.81)$ & $10(27.78)$ & $52(37.96)$ \\
\hline $\begin{array}{l}\text { Body mass index }\left(\mathrm{kg} / \mathrm{m}^{2}\right) \text { : } \\
\text { mean (SD) }\end{array}$ & $26.28(4.01)$ & $26.33(4.22)$ & $26.48(4.09)$ & $25.72(3.76)$ & $26.75(4.36)$ \\
\hline \multicolumn{6}{|c|}{ Waist circumference (cm): mean (SD) } \\
\hline Male & $93.27(9.42)$ & $91.79(9.62)$ & $94.45(9.36)$ & $91.64(10.91)$ & $93.99(11.48)$ \\
\hline Female & $88.68(9.81)$ & $86.49(11.41)$ & $88.01(9.83)$ & $88.60(9.10)$ & $90.57(10.15)$ \\
\hline
\end{tabular}


Table 1 Continued

\begin{tabular}{|c|c|c|c|c|c|}
\hline Characteristics & $\begin{array}{l}\text { Total } \\
\mathrm{N}=3011\end{array}$ & $\begin{array}{l}\text { FPG } 100-109 \mathrm{mg} / \mathrm{dL} \\
\text { and HbA1c }<5.7 \% \\
(\mathrm{~N}=223)\end{array}$ & $\begin{array}{l}\text { FPG } 100-109 \mathrm{mg} / \mathrm{dL} \\
\text { and HbA1c } 5.7 \%-6.49 \% \\
(\mathrm{~N}=456)\end{array}$ & $\begin{array}{l}\text { FPG } 110-125 \mathrm{mg} / \mathrm{dL} \\
\text { and HbA1c }<5.7 \% \\
(\mathrm{~N}=68)\end{array}$ & $\begin{array}{l}\text { FPG } 110-125 \mathrm{mg} / \mathrm{dL} \\
\text { and HbA1c } 5.7 \%-6.49 \% \\
(\mathrm{~N}=209)\end{array}$ \\
\hline $\begin{array}{l}\text { Systolic blood pressure (mm } \\
\mathrm{Hg}) \text { : mean (SD) }\end{array}$ & $137.09(14.07)$ & $134.45(12.94)$ & $136.48(13.89)$ & $136.80(12.30)$ & $136.92(13.72)$ \\
\hline $\begin{array}{l}\text { Diastolic blood pressure }(\mathrm{mm} \\
\mathrm{Hg}) \text { : mean (SD) }\end{array}$ & $76.99(6.31)$ & $77.87(6.38)$ & $77.54(5.95)$ & $78.59(6.53)$ & $77.71(6.55)$ \\
\hline $\begin{array}{l}\text { Serum triglyceride level (mg/ } \\
\mathrm{dL}) \text { : mean (SD) }\end{array}$ & $136.95(61.36)$ & $136.68(58.41)$ & $137.03(62.29)$ & $149.7(76.89)$ & $135.15(51.74)$ \\
\hline \multicolumn{6}{|c|}{ Serum uric acid $(\mathrm{mg} / \mathrm{dL})$ : mean $(\mathrm{SD})$} \\
\hline Male & $6.43(1.17)$ & $6.51(1.37)$ & $6.43(1.10)$ & $5.81(1.63)$ & $6.59(1.20)$ \\
\hline Female & $5.36(1.19)$ & $5.10(1.12)$ & $5.31(1.04)$ & $5.23(1.07)$ & $5.29(1.25)$ \\
\hline $\begin{array}{l}\text { LDL-cholesterol (mg/dL): } \\
\text { mean (SD) }\end{array}$ & $122.77(23.19)$ & $124.60(26.46)$ & $124.51(23.20)$ & $121.83(24.51)$ & $126.12(23.14)$ \\
\hline \multicolumn{6}{|c|}{ HDL-cholesterol (mg/dL): mean (SD) } \\
\hline Male & $49.11(10.78)$ & $49.48(11.46)$ & $47.96(10.12)$ & $50.25(9.42)$ & $46.95(9.45)$ \\
\hline Female & $56.15(12.39)$ & $56.22(12.21)$ & $56.23(11.54)$ & $56.43(13.36)$ & $54.86(12.77)$ \\
\hline FPG (mg/dL): mean (SD) & $107.18(5.61)$ & $104.14(2.67)$ & $104.09(2.60)$ & $113.61(3.35)$ & $114.65(4.11)$ \\
\hline HbA1c (\%): mean (SD) & $5.89(0.39)$ & $5.41(0.34)$ & $6.02(0.22)$ & $5.38(0.26)$ & $6.06(0.23)$ \\
\hline
\end{tabular}

FPG, fasting plasma glucose; HbA1c, hemoglobin A1c; HDL, high-density lipoprotein; LDL, low-density lipoprotein.

and female participants had $6.4( \pm 1.2) \mathrm{mg} / \mathrm{dL}$ and 5.4 $( \pm 1.2) \mathrm{mg} / \mathrm{dL}$ of serum uric acid. Mean FPG and HbAlc levels were $107.2( \pm 5.6) \mathrm{mg} / \mathrm{dL}$ and $5.9 \%( \pm 0.4)$. Characteristics of patients after performing multiple imputations are presented in online supplemental table 4.

\section{Progression rate to DM}

A total of 3011 patients contributed to 21285 personyears with a median follow-up time of 8 years (range: 6 months-29 years). The earliest date of pre-diabetes diagnosis in the study's participants was August 1986. Of them, 695 patients developed DM by either abnormal FPG or HbA1c with an estimated DM progression rate of $3.27 / 100$ person-years. A median time to DM progression was 15.23 years (95\% CI: 14.11 to 16.70 ) indicating $50 \%$ of patients converted to DM at about 15 years or longer after diagnosis of IFG. The IQR of DM progression was

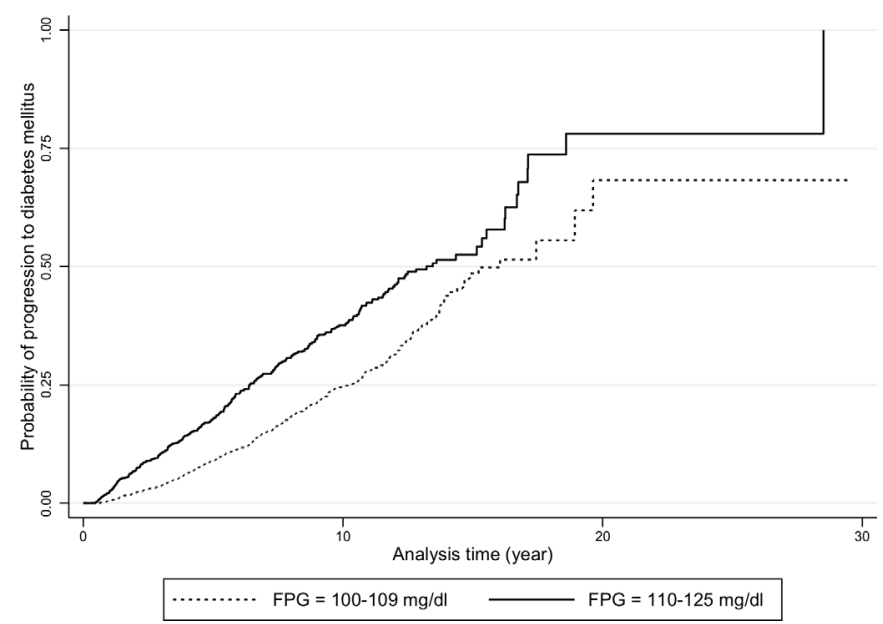

Figure 1 Progression rate to diabetes mellitus according to different cut-offs of fasting plasma glucose (FPG).
8.83-28.51 years. Furthermore, probabilities of DM progression at 5,10 , and 15 years were $11.52 \%$ (95\% CI: $10.38 \%$ to $12.78 \%$ ), $28.55 \%$ (95\% CI: $26.46 \%$ to $30.77 \%$ ), and $48.90 \%$ (95\% CI: $44.64 \%$ to $53.33 \%$ ), respectively.

\section{Progression rate to DM according to different FPG cut-offs}

Regarding the different levels of FPG, DM progression rates were 2.64 and 4.79/100 person-years for FPGs of 100-109 and $110-125 \mathrm{mg} / \mathrm{dL}$, respectively. In addition, time to DM conversion was shorter in patients with high FPG at baseline, that is, the median conversion times for these corresponding FPG groups were 16.05 and 13.22 years (see figure 1). Patients with FPG $110-125 \mathrm{mg} / \mathrm{dL}$ had significantly higher risk of DM progression with HR of 1.74 (95\% CI: 1.50 to 2.02 ) relative to FPG $100-109 \mathrm{mg} /$ $\mathrm{dL}$, respectively (table 2 ).

\section{Progression rate to DM when considering FPG and HbA1c together}

Incidence rate of DM was highest in patients having $\mathrm{FPG}_{110-125}$ and $\mathrm{HbAlc}_{5.7-6.49}$ (5.46/100 person-years), followed by $\mathrm{FPG}_{100-109}$ and $\mathrm{HbAlc}_{5.7-6.49}(3.55 / 100$ personyears), $\mathrm{FPG}_{110-125}$ and $\mathrm{HbAlc}_{<5.7}(1.05 / 100$ person-years $)$, and $\mathrm{FPG}_{100-109}$ and $\mathrm{HbAlc}_{<5.7}(0.24 / 100$ person-years) (see figure 2). When compared with patients with $\mathrm{FPG}_{100-109}$ and $\mathrm{HbAlc}_{<5.7}$, those with $\mathrm{FPG}_{110-125}$ and $\mathrm{HbAlc}_{<5.7}, \mathrm{FPG}_{100-}$ ${ }_{109}$ and $\mathrm{HbAlc}_{5.7-6.49}$, and $\mathrm{FPG}_{110-125}$ and $\mathrm{HbAlc}_{5.7-6.49}$ had significantly higher risk of DM with HRs $(95 \% \mathrm{CI})$ of 4.20 (1.75 to 10.09), 14.53 (7.76 to 27.22), and 21.50 (11.44 to 40.39), respectively (table 2 ). In addition, patients with $\mathrm{FPG}_{110-125}$ and $\mathrm{HbAlc}_{5,7-6.49}$ had a significantly higher risk of DM than patients having $\mathrm{FPG}_{110-125}$ and $\mathrm{HbAlc}_{<5.7}$ (HR=5.74; 95\% CI: 3.02 to 10.90 ).

Proportional hazards assumption of FPG-HbAlc effect was checked by constructing a log-log plot of FPG-HbA1c 
Table 2 Factors associated with conversion of diabetes mellitus: a univariate Cox regression analysis

\begin{tabular}{|c|c|c|c|c|c|}
\hline Factor & Time at risk & Number of event & $\begin{array}{l}\text { Incidence rate/ } \\
100 \text { patient-years }\end{array}$ & HR & $95 \% \mathrm{Cl}$ \\
\hline \multicolumn{6}{|c|}{$\mathrm{FPG}(\mathrm{mg} / \mathrm{dL})$} \\
\hline $100-109$ & 15080 & 398 & 2.64 & 1 & \\
\hline $110-125$ & 6205 & 297 & 4.79 & 1.74 & 1.50 to 2.02 \\
\hline \multicolumn{6}{|l|}{ HbA1c (\%) } \\
\hline$<5.7$ & 5110 & 20 & 0.39 & 1 & \\
\hline $5.7-6.49$ & 16175 & 675 & 4.17 & 10.43 & 6.68 to 16.26 \\
\hline
\end{tabular}

Combined FPG (mg/dL) and $\mathrm{HbA} 1 \mathrm{c}(\%)$

$100-109$ and $<5.7$
$110-125$ and $<5.7$
$100-109$ and $5.7-6.49$
$110-125$ and $5.7-6.49$

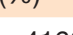

Age at diagnosis pre-diabetes (years)

\begin{tabular}{|c|c|c|c|c|c|}
\hline$<65$ & 16669 & 541 & 3.25 & 1 & \\
\hline $65-75$ & 3963 & 123 & 3.10 & 0.997 & 0.82 to 1.21 \\
\hline$\geq 75$ & 653 & 31 & 4.75 & 1.628 & 1.13 to 2.34 \\
\hline Male & 7213 & 225 & 3.12 & 1 & \\
\hline Female & 14072 & 470 & 3.34 & 1.07 & 0.91 to 1.25 \\
\hline
\end{tabular}

\section{Educational level}

Non-educated

Primary school

$951 \quad 10$

0.24

$10920 \quad 388$

1.05

3.55

.20

1.75 to 10.09

$5254 \quad 287$

5.46

7.76 to 27.22

14.53

11.44 to 40.39

Secondary school

College or higher

$\begin{array}{rr}571 & 30 \\ 7090 & 232 \\ 6093 & 209 \\ 7532 & 224\end{array}$

1.07

0.91 to 1.25

Reimbursement

$\begin{array}{lrr}\text { UHC } & 375 & 13 \\ \text { SSS } & 1963 & 82 \\ \text { Civil servant } & 12785 & 402 \\ \text { Other } & 6162 & 198\end{array}$

Body mass index $\left(\mathrm{kg} / \mathrm{m}^{2}\right)$

$<23$

23-27.5

$\geq 27.5$

Family history of DM

No

Yes

Smoking status

$\begin{array}{lrr}\text { Never } & 16270 & 536 \\ \text { Past } & 4282 & 131 \\ \text { Current } & 733 & 28\end{array}$

Alcohol drinking

\begin{tabular}{|c|c|c|c|c|c|}
\hline Never & 11720 & 391 & 3.34 & 1 & \\
\hline Past & 5711 & 175 & 3.06 & 0.91 & 0.76 to 1.09 \\
\hline Current & 3854 & 129 & 3.35 & 1.04 & 0.85 to 1.27 \\
\hline No & 12857 & 379 & 2.95 & 1 & \\
\hline Yes & 8427 & 316 & 3.75 & 1.27 & 1.10 to 1.48 \\
\hline
\end{tabular}

Continued 
Table 2 Continued

\begin{tabular}{|c|c|c|c|c|c|}
\hline Factor & Time at risk & Number of event & $\begin{array}{l}\text { Incidence rate/ } \\
100 \text { patient-years }\end{array}$ & HR & $95 \% \mathrm{Cl}$ \\
\hline \multicolumn{6}{|l|}{ Blood pressure } \\
\hline Normal BP* and no $\mathrm{HT}^{*}$ & 4232 & 112 & 2.70 & 1 & \\
\hline $\begin{array}{l}\text { Well-controlled } \mathrm{BP}^{*} \text { with } \mathrm{HT} \text { and/ } \\
\text { or antihypertensive drugs }\end{array}$ & 7947 & 240 & 3.00 & 1.09 & 0.85 to 1.38 \\
\hline High BP† with or without HT & 9106 & 342 & 3.80 & 1.33 & 1.05 to 1.68 \\
\hline \multicolumn{6}{|l|}{ Hyperuricemia } \\
\hline Noł & 15286 & 448 & 2.90 & 1 & \\
\hline Yes§ & 5999 & 247 & 4.10 & 1.40 & 1.19 to 1.64 \\
\hline \multicolumn{6}{|l|}{ Triglyceride } \\
\hline$<150 \mathrm{mg} / \mathrm{dL}$ & 14029 & 398 & 2.83 & 1 & \\
\hline$\geq 150 \mathrm{mg} / \mathrm{dL}$ & 7255 & 297 & 4.10 & 1.45 & 1.24 to 1.70 \\
\hline \multicolumn{6}{|l|}{ LDL-cholesterol } \\
\hline$<130 \mathrm{mg} / \mathrm{dL}$ & 13108 & 429 & 3.30 & 1 & \\
\hline$\geq 130 \mathrm{mg} / \mathrm{dL}$ & 8177 & 266 & 3.30 & 1.03 & 0.89 to 1.21 \\
\hline \multicolumn{6}{|l|}{ HDL-cholesterol } \\
\hline$<40$ in male, $<50$ in female & 6119 & 251 & 4.10 & 1 & \\
\hline$\geq 40$ in male, $\geq 50$ in female & 15165 & 444 & 2.90 & 0.70 & 0.60 to 0.82 \\
\hline
\end{tabular}

*Systolic BP $<140 \mathrm{~mm} \mathrm{Hg}$ and diastolic BP $<90 \mathrm{~mm} \mathrm{Hg}$.

†Systolic BP $\geq 140 \mathrm{~mm} \mathrm{Hg}$ and/or diastolic $90 \mathrm{~mm} \mathrm{Hg}$.

$\ddagger$ Serum uric acid $<6 \mathrm{mg} / \mathrm{dL}$ in female and $<7.2$ in male

$\S$ Serum uric acid $\geq 6 \mathrm{mg} / \mathrm{dL}$ in female and $\geq 7.2 \mathrm{mg} / \mathrm{dL}$ in male.

$\mathrm{BP}$, blood pressure; DM, diabetes mellitus; FPG, fasting plasma glucose; HbA1c, hemoglobin A1c; HDL, high-density lipoprotein; HR, hazard ratio;

HT, hypertension; LDL, low-density lipoprotein; SSS, social security scheme; UHC, universal healthcare coverage.

groups (see online supplemental figure 1) indicating the four curves looked parallel, except for $\mathrm{FPG}_{100-109}$ and $\mathrm{HbAl}_{5.7-6.49}$, and $\mathrm{FPG}_{110-125}$ and $\mathrm{HbAlc}_{<5.7}$ groups that were cross-over, that is, effects of the two groups were varied over time. This was corresponded with the global $\mathrm{X}^{2}$ test $\left(\mathrm{X}^{2}=27.25, \mathrm{df}=3, \mathrm{p}<0.001\right)$.

\section{Factors associated with the risk of DM}

Univariate Cox regression analysis indicated that age at IFG diagnosis, education, family history of DM, BMI,

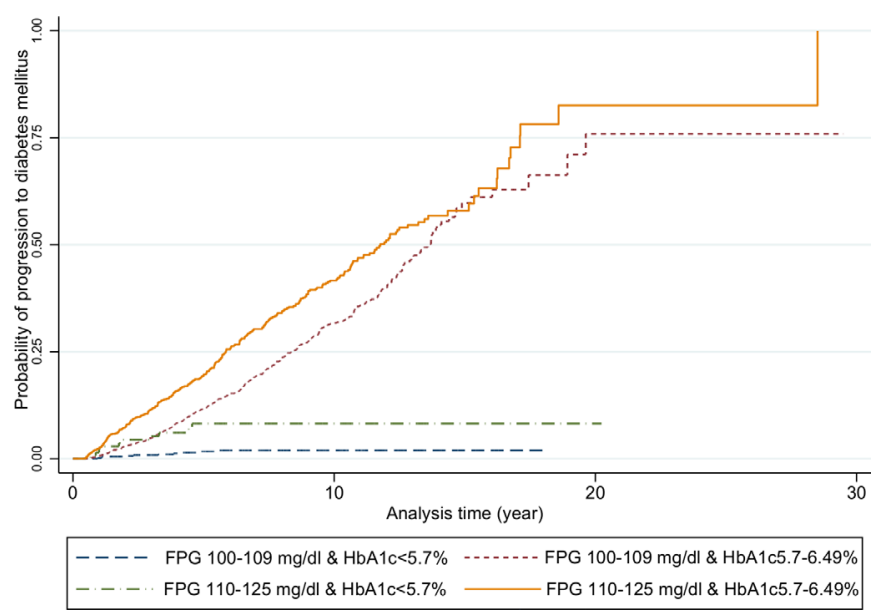

Figure 2 Progression rate to diabetes mellitus when considering fasting plasma glucose (FPG) and hemoglobin A1c (HbA1c) together.
OSA risk, history of hypertension and blood pressure level, serum uric acid, triglyceride, and HDL-C level had a $p$ value of less than 0.10 (table 2).

A multivariate Cox regression with FPG and HbA1c adjusting for time-varying effects indicated that $\mathrm{FPG}_{110-125}$ and $\mathrm{HbAlc}_{<5.7}, \mathrm{FPG}_{100-109}$ and $\mathrm{HbAlc}_{5.7-6.49}$, and $\mathrm{FPG}_{110-}$ 125 and HbA1 $c_{5.7-6.49}$ significantly increased risk of DM conversion when compared with $\mathrm{FPG}_{100-109}$ and $\mathrm{HbA1} \mathrm{c}_{557}$ with HRs $(95 \% \mathrm{CI}$ ) of 5.89 (2.37 to 14.63), 16.30 (8.59 to 30.92 ), and 33.84 (16.41 to 69.78), respectively (see table 3 ). In addition, family history of DM, BMI $\geq 27.5 \mathrm{~kg} /$ $\mathrm{m}^{2}$, and high triglyceride level were also significantly associated with DM conversion after adjusting with baseline FPG-HbA1c with HRs (95\% CI) of 1.27 (1.09 to 1.47), 1.67 (1.30 to 2.15 ), and 1.40 (1.19 to 1.64 ), respectively (see table 3). Contrastingly, high HDL-C level significantly decreased risk of DM with HR $(95 \% \mathrm{CI})$ of 0.82 $(0.70$ to 0.96$)$.

\section{DISCUSSION}

We had conducted a cohort study of 3011 patients with IFG, with median follow-up time of 8 years. Our findings suggest that overall progression rate to DM was 3.27 per 100 person-years with a median DM conversion of 15 years. Risk of DM increased when levels of FPG increased such that patients having FPG 110-125 mg/ $\mathrm{dL}$ progressed to DM significantly greater than patients having FPG $100-109 \mathrm{mg} / \mathrm{dL}$. When considering FPG 
Table 3 Factors associated with diabetes conversion: a multivariate Cox regression with time-varying model

\begin{tabular}{|c|c|c|c|}
\hline Factor & HR & $95 \% \mathrm{Cl}$ & $P$ value \\
\hline \multicolumn{4}{|c|}{ Combined FPG (mg/dL) and HbA1c (\%) } \\
\hline $100-109$ and $<5.7$ & 1 & & \\
\hline $110-125$ and $<5.7$ & 5.89 & 2.37 to 14.63 & $<0.001$ \\
\hline $100-109$ and $5.7-6.49$ & 16.30 & 8.59 to 30.92 & $<0.001$ \\
\hline $110-125$ and $5.7-6.49$ & 33.84 & 16.41 to 69.78 & $<0.001$ \\
\hline \multicolumn{4}{|l|}{ Body mass index $\left(\mathrm{kg} / \mathrm{m}^{2}\right)$} \\
\hline$<23$ & 1 & & \\
\hline $23-27.5$ & 1.26 & 0.98 to 1.62 & 0.067 \\
\hline$\geq 27.5$ & 1.67 & 1.30 to 2.15 & $<0.001$ \\
\hline \multicolumn{4}{|l|}{ Family history of DM } \\
\hline No & 1 & & \\
\hline Yes & 1.27 & 1.09 to 1.47 & 0.002 \\
\hline \multicolumn{4}{|l|}{ Triglyceride (mg/dL) } \\
\hline$<150$ & 1 & & \\
\hline$\geq 150$ & 1.40 & 1.19 to 1.64 & $<0.001$ \\
\hline \multicolumn{4}{|l|}{ HDL-cholesterol (mg/dL) } \\
\hline$<40$ in male, $<50$ in female & 1 & & \\
\hline$\geq 40$ in male, $\geq 50$ in female & 0.82 & 0.70 to 0.96 & 0.015 \\
\hline
\end{tabular}

DM, diabetes mellitus; FPG, fasting plasma glucose; HbA1c, hemoglobin A1c; HDL, high-density lipoprotein; HR, hazard ratio.

and HbAlc levels together, at the same FPG levels, incidence rate of DM was higher for those with abnormal HbA1c. Regarding the risk factor of DM, BMI $\geq 27.5 \mathrm{~kg} /$ $\mathrm{m}^{2}$, having family history of DM, high triglyceride level greater than $150 \mathrm{mg} / \mathrm{dL}$, and low HDL-C level are found to be independently associated with DM risk in patients with IFG.

Pre-diabetes referred to people with high glucose level but not within diabetes range. Several criteria based on FPG, HbA1c and oral glucose tolerance test (OGTT) have been used to define pre-diabetes stage. Although the ADA and IEC have adopted HbAlc as one of the diagnosis criteria, the HbAlc criterion has not been supported by WHO and other organizations. Results of previous studies suggested that HbAlc is an accurate method for DM and pre-diabetes diagnosis and had better predictive capacity than FPG ${ }^{21}$ Findings from our study also confirm the benefit of using HbAlc in combination with FPG to estimate the progression rate of DM and classify patients with IFG to be high or low risk of DM. Our results corresponded to the findings from previous meta-analyses ${ }^{11} 22$ and cohort studies ${ }^{19} 202324$ that patients with combined IFG and abnormal HbAlc had significantly higher risk of DM than patients with IFG alone. In addition to the prediction of DM risk, results from large prospective cohort studies ${ }^{2325}$ found that prediabetes defined by HbAlc criteria conferred a significantly higher risk of CVDs, CKD and all-cause mortality. Therefore, using HbAlc in addition to FPG is useful for identifying people who are at high risk of DM and also CVD.

According to FPG-based criteria, the FPG thresholds used to define IFG are different between ADA (100$125 \mathrm{mg} / \mathrm{dL})$ and WHO $(110-125 \mathrm{mg} / \mathrm{dL})$. Our study found that when compared with FPG $100-109 \mathrm{mg} / \mathrm{dL}$, incidence rate of DM was significantly higher in those with FPG 110-125 mg/dL. In addition, incidence rate of DM in participants with $\mathrm{FPG}_{100-109}$ and $\mathrm{HbAlc}_{<5.7}$ was only 1.16 per 100 person-years, while incidence rate of DM in those with $\mathrm{FPG}_{100-109}$ and $\mathrm{HbAlc}_{5.7-6.49}$ was 4.62 per 100 person-years. Therefore, among all definitions of prediabetes, patients with $\mathrm{FPG}_{100-109}$ and $\mathrm{HbAlc}_{<5.7}$ had the lowest risk of DM progression.

The ADA applies FPG of $100-125 \mathrm{mg} / \mathrm{dL}$ to define IFG because this threshold is more comparable with IGT and can expand the sensitivity for predicting incidence of DM in many populations. ${ }^{26}$ However, using the FPG $100-125 \mathrm{mg} / \mathrm{dL}$ for defining IFG will increase the prevalence of pre-diabetes and consequently might increase health and economic burdens, especially in low and limited-resource settings. Moreover, there has been no evidence of additional benefit of lowering FPG threshold to $100 \mathrm{mg} / \mathrm{dL}$ in terms of predicting the DM risk or complications of DM. ${ }^{27}$ Therefore, our findings support the more advantage of using FPG combined with HbAlc values to predict risk of DM in the future.

Regarding the risk factors of DM, our study found that only BMI $\geq 27 \mathrm{~kg} / \mathrm{m}^{2}$, having family history of DM, serum triglyceride level $\geq 150 \mathrm{mg} / \mathrm{dL}$, and low level of HDL-C were significantly associated with DM in patients with prediabetes. Risk factors of DM found in our study are similar to the established risk factors of DM that are applied as the criteria for DM screening in asymptomatic adults. ${ }^{17}$ Previous systematic reviews and meta-analyses suggest significant relationship between $\mathrm{OSA}^{28}$ and serum uric acid. ${ }^{29}{ }^{30}$ However, neither sleep factors nor serum uric acid was significantly associated with DM in our study.

\section{Strength and limitation}

Our study is an ambidirectional cohort study that combined retrospective and prospective data collection. The time since IFG diagnosis was used to estimate progression rate to DM instead of the time since enrollment. Thus, the follow-up time of our study is long enough to represent the natural history of IFG in the realworld setting. Moreover, since some variables (ie, BMI, SBP, DBP, serum uric acid, triglyceride, LDL-C, HDL-C) were measured more than once, our study considered all values of these variables and treated them as time-varying covariates in the analysis. This method is more accurate than considering only baseline value to estimate the risk of DM. However, our study has limitations. First, this study is a hospital-based cohort where study participants might have higher cardiometabolic risk than the general population. In addition, the proportion of female participants and per cent of current and past alcohol drinkers were high in our study, Therefore, the representativeness 
of our study for Thai population might be questionable. Second, our study used some data, such as blood pressures and laboratory data from routine clinical practice. Thus, numbers of measurements and duration between each visit varied among participants. Third, about $68.9 \%$ of patients had missing HbAlc value at baseline, therefore, $\mathrm{HbAlc}$ measurements within 2 years after diagnosis of IFG were used along with applying multiple imputations to predict these missing HbAlc values and other missing covariables. Although imputation models were robust, effect size of HbAlc and the other prognostic factors might be still questionable. Finally, OGTT was not performed. Therefore, the progression rate of DM in patients with IGT could not be estimated. However, OGTT is generally not performed in a routine clinical practice due to its low reproducibility, high cost, and prolonged time required for the test.

\section{Clinical implications}

The data from the previous evidence showed that prediabetes is not only related to an increased risk of DM but also related to microvascular and macrovascular complications. However, not all people with pre-diabetes will progress to $\mathrm{DM}^{6}{ }^{6}$ Therefore, the diabetes prevention strategies should focus on individuals with high risk of progression to DM in order to maximize the benefit from targeted prevention. The result of our study suggested that using HbAlc in combination with FPG in clinical practice could identify subgroups of people with IFG who were at highest risk of progressing to DM. However, HbAlc test may not be routinely performed, especially in low-resource settings, due to its high cost and requirement of test standardization. Thus, further research is needed to determine whether the use of combination of FPG and HbA1c for pre-diabetes diagnosis is cost-effective in terms of prevention of DM and its complications.

\section{CONCLUSION}

Patients with combined IFG and abnormal HbAlc had the highest risk of DM. Using HbA1c in combination with FPG could identify subgroups of people with IFG at highest risk of progression to DM. Therefore, in settings with limited resources, people with combined IFG and abnormal HbAlc should have the highest priority in diabetes prevention programs.

\section{Author affiliations \\ ${ }^{1}$ Department of Family Medicine, Faculty of Medicine, Ramathibodi Hospital, Mahidol University, Bangkok, Thailand \\ ${ }^{2}$ Department of Clinical Epidemiology and Biostatistics, Faculty of Medicine, Ramathibodi Hospital, Mahidol University, Bangkok, Thailand \\ ${ }^{3}$ Department of Endocrinology, Diabetes, and Metabolism, Department of Medicine, University of Illinois at Chicago, Chicago, Illinois, USA}

Contributors ST, TA, SRe, and AT designed the study and developed the methodology. ST, TA, and KS recruited participants and collected the data. NU and SRa performed data management. SRa and AT analyzed the data. ST, TA, and KS wrote the manuscript and interpreted the results. TA, SRe, and AT reviewed the analysis, interpretations and manuscript and did the final review. ST, TA, KS, NU, $\mathrm{SRa}$, SRe, and AT critically reviewed the manuscript. TA is the guarantor of this work and, as such, had access to all data and takes responsibility for the integrity of the data and the accuracy of the data analysis.

Funding This work was supported by the Faculty of Medicine, Ramathibodi Hospital, Mahidol University, Bangkok, Thailand (grant number CF_64009).

Competing interests None declared.

Patient consent for publication Not required.

Ethics approval All patients signed and gave a written informed consent before enrollment to the study. The study protocol was approved by the Institutional Review Board (IRB) of the Faculty of Medicine, Ramathibodi Hospital, Mahidol University (MURA2018/590).

Provenance and peer review Not commissioned; externally peer reviewed.

Data availability statement Data may be obtained from a third party and are not publicly available. Data are not publicly available because the follow up data collection is ongoing.

Supplemental material This content has been supplied by the author(s). It has not been vetted by BMJ Publishing Group Limited (BMJ) and may not have been peer-reviewed. Any opinions or recommendations discussed are solely those of the author(s) and are not endorsed by BMJ. BMJ disclaims all liability and responsibility arising from any reliance placed on the content. Where the content includes any translated material, BMJ does not warrant the accuracy and reliability of the translations (including but not limited to local regulations, clinical guidelines, terminology, drug names and drug dosages), and is not responsible for any error and/or omissions arising from translation and adaptation or otherwise.

Open access This is an open access article distributed in accordance with the Creative Commons Attribution Non Commercial (CC BY-NC 4.0) license, which permits others to distribute, remix, adapt, build upon this work non-commercially, and license their derivative works on different terms, provided the original work is properly cited, appropriate credit is given, any changes made indicated, and the use is non-commercial. See: http://creativecommons.org/licenses/by-nc/4.0/.

ORCID iD

Thunyarat Anothaisintawee http://orcid.org/0000-0003-1002-8536

\section{REFERENCES}

1 American Diabetes Association. 2. Classification and Diagnosis of Diabetes: Standards of Medical Care in Diabetes-2019. Diabetes Care 2019;42:S13-28.

2 Beulens J, Rutters F, Rydén L, et al. Risk and management of prediabetes. Eur J Prev Cardiol 2019;26:47-54.

3 Wang H, Ba Y, Cai R-C, et al. Association between diabetes mellitus and the risk for major cardiovascular outcomes and allcause mortality in women compared with men: a meta-analysis of prospective cohort studies. BMJ Open 2019;9:e024935.

4 Huang Y, Cai X, Mai W, et al. Association between prediabetes and risk of cardiovascular disease and all cause mortality: systematic review and meta-analysis. BMJ 2016;355:i5953.

5 Wilson ML. Prediabetes: beyond the borderline. Nurs Clin North Am 2017;52:665-77.

6 Tabák AG, Herder C, Rathmann W, et al. Prediabetes: a high-risk state for diabetes development. Lancet 2012;379:2279-90.

7 American Diabetes Association. 2. classification and diagnosis of diabetes. Diabetes Care 2017;40:S11-24.

8 World Health Organization. Definition and diagnosis of diabetes mellitus and intermediate hyperglycemia: report of a $\mathrm{WHO} /$ IDF consultation, 2006. Available: http://www.who.int/diabetes/ publications/Definition and diagnosis of diabetes_new.pdf [Accessed 20 Aug 2020].

9 Forouhi NG, Luan J, Hennings S, et al. Incidence of type 2 diabetes in England and its association with baseline impaired fasting glucose: the Ely study 1990-2000. Diabet Med 2007;24:200-7.

10 Vilanova MB, Falguera M, Marsal JR, et al. Prevalence, clinical features and risk assessment of pre-diabetes in Spain: the prospective Mollerussa cohort study. BMJ Open 2017;7:e015158.

11 Lee CMY, Colagiuri S, Woodward M, et al. Comparing different definitions of prediabetes with subsequent risk of diabetes: an individual participant data meta-analysis involving 76513 individuals and 8208 cases of incident diabetes. BMJ Open Diabetes Res Care 2019;7:e000794.

12 Lorenzo C, Wagenknecht LE, Hanley AJG, et al. A1C between 5.7 and $6.4 \%$ as a marker for identifying pre-diabetes, insulin sensitivity and secretion, and cardiovascular risk factors: the Insulin Resistance Atherosclerosis Study (IRAS). Diabetes Care 2010;33:2104-9. 
13 Færch K, Johansen NB, Witte DR, et al. Relationship between insulin resistance and $\beta$-cell dysfunction in subphenotypes of prediabetes and type 2 diabetes. J Clin Endocrinol Metab 2015;100:707-16.

14 Buijsse B, Simmons RK, Griffin SJ, et al. Risk assessment tools for identifying individuals at risk of developing type 2 diabetes. Epidemiol Rev 2011;33:46-62.

15 Netzer NC, Stoohs RA, Netzer CM, et al. Using the Berlin questionnaire to identify patients at risk for the sleep apnea syndrome. Ann Intern Med 1999;131:485-91.

16 WHO Expert Consultation. Appropriate body-mass index for Asian populations and its implications for policy and intervention strategies. Lancet 2004;363:157-63.

17 American Diabetes Association. 2. Classification and Diagnosis of Diabetes: Standards of Medical Care in Diabetes-2020. Diabetes Care 2020;43:S14-31.

18 Bennasar-Veny M, Fresneda S, López-González A, et al. Lifestyle and progression to type 2 diabetes in a cohort of workers with prediabetes. Nutrients 2020;12. doi:10.3390/nu12051538. [Epub ahead of print: 25 May 2020].

19 Heianza Y, Hara S, Arase Y, et al. HbA1c 5·7-6.4\% and impaired fasting plasma glucose for diagnosis of prediabetes and risk of progression to diabetes in Japan (TOPICS 3): a longitudinal cohort study. Lancet 2011;378:147-55.

20 Schmidt MI, Bracco PA, Yudkin JS, et al. Intermediate hyperglycaemia to predict progression to type 2 diabetes (ELSABrasil): an occupational cohort study in Brazil. Lancet Diabetes Endocrinol 2019;7:267-77.

21 Sacks DB. A1C versus glucose testing: a comparison. Diabetes Care 2011;34:518-23.
22 Richter B, Hemmingsen B, Metzendorf M-I, et al. Development of type 2 diabetes mellitus in people with intermediate hyperglycaemia. Cochrane Database Syst Rev 2018;10:CD012661.

23 Warren B, Pankow JS, Matsushita K, et al. Comparative prognostic performance of definitions of prediabetes: a prospective cohort analysis of the Atherosclerosis risk in communities (ARIC) study. Lancet Diabetes Endocrinol 2017:5:34-42.

24 Safari S, Amini M, Aminorroaya A, et al. Patterns of changes in fasting plasma glucose, hemoglobin A1c and the area under the curve during oral glucose tolerance tests in prediabetic subjects: results from a 16-year prospective cohort study among first-degree relatives of type 2 diabetic patients. Acta Diabetol 2021;58:371-81.

25 Emerging Risk Factors Collaboration, Di Angelantonio E, Gao P, et al. Glycated hemoglobin measurement and prediction of cardiovascular disease. JAMA 2014;311:1225-33.

26 Genuth S, Alberti KGMM, Bennett P, et al. Follow-up report on the diagnosis of diabetes mellitus. Diabetes Care 2003;26:3160-7.

27 Echouffo-Tcheugui JB, Kengne AP, Ali MK. Issues in defining the burden of prediabetes globally. Curr Diab Rep 2018;18:105.

28 Qie R, Zhang D, Liu L, et al. Obstructive sleep apnea and risk of type 2 diabetes mellitus: a systematic review and dose-response metaanalysis of cohort studies. J Diabetes 2020;12:455-64.

29 Xu Y-L, Xu K-F, Bai J-L, et al. Elevation of serum uric acid and incidence of type 2 diabetes: A systematic review and metaanalysis. Chronic Dis Transl Med 2016;2:81-91.

30 Kodama S, Saito K, Yachi Y, et al. Association between serum uric acid and development of type 2 diabetes. Diabetes Care 2009;32:1737-42. 